\title{
Anticorrosive water borne paints free from zinc and with reduced phosphate content
}

\author{
Sol N. Roselli ${ }^{\mathrm{a}, \mathrm{c}}$, Gabriela Lendvay-Györik ${ }^{\mathrm{b}}$, Gabor Mészáros ${ }^{\mathrm{b}}$, Cecilia Deyáa,c \\ Roberto Romagnoli ${ }^{\mathrm{a}, \mathrm{d}, *}$ \\ a CIDEPINT - Centro de Investigación y Desarrollo en Tecnología de Pinturas, (CIC-CONICET), Calle 52 e/121 y 122, 1900 La Plata, Argentina \\ b Institute of Materials and Environmental Chemistry, Chemical Research Center, Hungarian Academy of Sciences, Pusztaszeri út 59-67, P.O. Box 17, H-25 Budapest, \\ Hungary \\ ${ }^{c}$ Facultad de Ingeniería, Universidad Nacional de La Plata, Av. $7 n^{\circ} 877,1900$ La Plata, Argentina \\ ${ }^{\text {d }}$ Facultad de Ciencias Exactas, Universidad Nacional de La Plata, Av. $7 n^{\circ}$ 877, 1900 La Plata, Argentina
}

\section{A R T I C L E I N F O}

\section{Keywords:}

Coatings

Electrochemical noise

FTIR

Corrosion

\begin{abstract}
A B S T R A C T
The objective of this research was to formulate water-borne epoxy coatings free from zinc and with reduced phosphate levels, replacing zinc phosphate by calcium acid phosphate. Lanthanum molybdate was incorporated as a green anticorrosive pigment to enhance paint anticorrosive performance. Paints were assessed by accelerated (salt spray and humidity chambers) and electrochemical tests (ionic resistance and electrochemical noise).

Results suggested that zinc phosphate could be replaced by calcium acid phosphate and the phosphate content in the paint film reduced to one third. Lanthanum molybdate can act synergistically with phosphates.
\end{abstract}

\section{Introduction}

One of the most important challenges in the field of paint technology are concerned with the development of safer products, safer processes and reduced solvent emissions to the atmosphere with zero emissions as the most relevant achievement [1]. In the case of anticorrosive paints safer products means, primarily, the complete elimination of chromates and the employment of water instead of organic solvents. In this sense, from 1970 on, two major goals were achieved in the field of paint technology: the replacement of toxic inhibitive pigments containing lead and chromate compounds by phosphates and the progressive elimination of organic solvents in paint formulations to fit VOC's regulations.

Three generations of phosphates were introduced in the market, being zinc phosphate the precursor [1-11]. Zinc phosphate nanoparticles were reported to perform better than normal micrometric ones [12]. The second generation was developed by performing suitable modifications in the zinc phosphate particle [6-14]. Finally, the third generation was designed to meet high technological applications and was obtained changing the orthophosphate anion by the polyphosphate ones [15-25]. Both, the second and the third generation of phosphate pigments are claimed to have equal or superior anticorrosive behavior than chromates and better than zinc phosphate on its own [26-29].

The synergism between phosphate based pigments has been studied. The interaction between molybdate and phosphate anions as well as zinc and/or calcium cation have been reported $[3,7,8]$.

Other anticorrosive pigments, apart from phosphates, were found to be suitable to formulate anticorrosive paints. Among them, condensed phosphates [30], double phosphates of the formula $\mathrm{MM}\left(\mathrm{PO}_{4}\right)_{\mathrm{n}}$, being $\mathrm{M}$ a metal cation [31], boron phosphates [32], calcium metaborate [32], ferrites [8,33,34], exchanged silicas and exchanged clays [34,35], anion exchange pigments [36], intrinsic conductive polymers [37,38], spinel-type compounds [30], etc.

Besides, anticorrosive pigments can act sinergically as zinc phosphate and zinc hipophosphate.

The elimination of solvents was accomplished in different ways. One of the most important is concerned with the development of waterborne systems. These systems present a range of characteristic differences and, in some cases, difficulties not exhibited by solvent-borne paints [39-43]. It was stated everywhere that water-borne paints are less resistant to the corrosion process and prone to biological attack [40,44-47]. They also exhibit "flash rusting" during solvent evaporation which finally affects the appearance of the coating $[44,47]$.

The objective of this research was to formulate water-borne coatings

\footnotetext{
* Corresponding author at: CIDEPINT - Centro de Investigación y Desarrollo en Tecnología de Pinturas, (CIC-CONICET), Calle 52 e/121 y 122,1900 La Plata, Argentina. Fax: + 54 221 4271537.

E-mail addresses: gyorik@chemres.hu (G. Lendvay-Györik), estelectro@cidepint.gov.ar (R. Romagnoli).
} 
Table 1

Paints composition.

\begin{tabular}{|c|c|c|c|c|c|c|c|c|c|}
\hline Components & 1 & 2 & 3 & 4 & 5 & 6 & 7 & Blank & Trademark \\
\hline Lanthanum molybdate & 0.6 & 0.6 & 0.6 & - & - & 3.6 & - & - & Prepared in the laboratory \\
\hline Calcium acid phosphate & 0.6 & 1.8 & 3.0 & 1.2 & 2.4 & - & 3.6 & - & \\
\hline $\mathrm{TiO}_{2}$ & 3.1 & 2.8 & 2.4 & 3.1 & 2.8 & 2.4 & 2.4 & 3.4 & Zamudio \\
\hline Talc & 3.0 & 2.6 & 2.3 & 3.0 & 2.6 & 2.3 & 2.3 & 3.3 & Minera Cema \\
\hline Mica & 2.6 & 2.3 & 2.0 & 2.6 & 2.3 & 2.0 & 2.0 & 2.9 & Minera Cema \\
\hline Barium sulphate & 2.0 & 1.8 & 1.6 & 2.0 & 1.8 & 1.6 & 1.6 & 2.3 & Minera Cema \\
\hline Resin & 35.7 & 35.7 & 35.7 & 35.7 & 35.7 & 35.7 & 35.7 & 35.7 & (Huntsman, Py340) \\
\hline Curing agent (hardener) & 29.8 & 29.8 & 29.8 & 29.8 & 29.8 & 29.8 & 29.8 & 29.8 & (Huntsman, HZ340) \\
\hline Distilled water & 21.0 & 21.0 & 21.0 & 21.0 & 21.0 & 21.0 & 21.0 & 21.0 & Prepared in the laboratory \\
\hline Antifoaming & 0.5 & 0.5 & 0.5 & 0.5 & 0.5 & 0.5 & 0.5 & 0.5 & Diransa, Q202 \\
\hline Neutralizing amine & 1.1 & 1.1 & 1.1 & 1.1 & 1.1 & 1.1 & 1.1 & 1.1 & Dow, AMP-95 \\
\hline
\end{tabular}

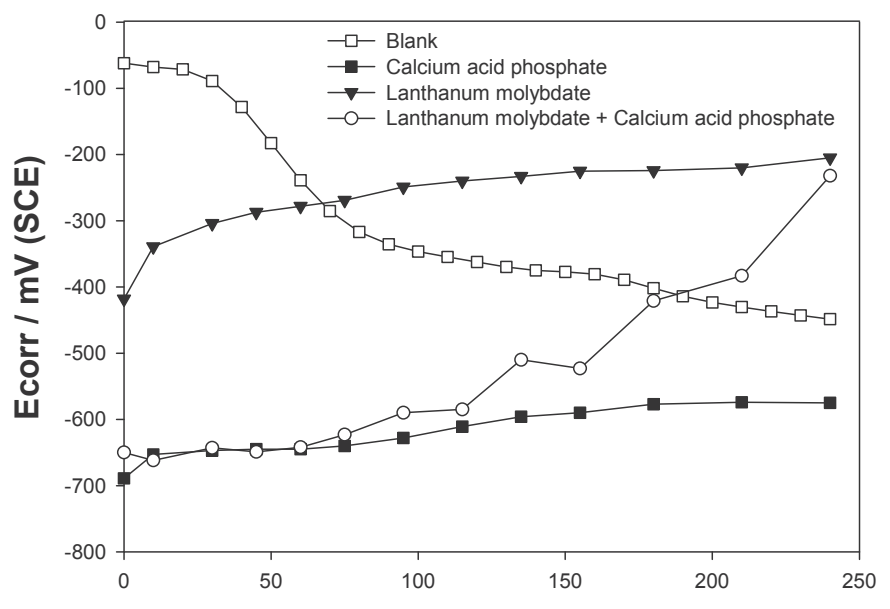

Time / min

Fig. 1. Corrosion potential of steel immersed in different pigment suspensions.

free from zinc and with reduced phosphate levels. Zinc phosphate was completely replaced by calcium acid phosphate and lanthanum molybdate was added to enhance paint anticorrosive performance. Lanthanum molybdate was selected based on the successful employment of the analogue cerium molybdate while calcium phosphate was previously studied in our laboratory [48-50]. Lanthanides salts were successfully used as cathodic anticorrosion inhibitors to protect metals when exposed to an aggressive solutions, for protection at high temperatures [51], to improve the adherence of oxide films of different metallic alloys by ionic implantation, etc. [52,53]. Paints were assessed by accelerated tests (salt spray and humidity chambers) and ionic resistance and electrochemical noise measurements (ENM). ENM can be used for ranking high-impedance coating systems [54-56].

Results suggested that zinc phosphate could be replaced by calcium acid phosphate and the phosphate content in the paint film reduced to one third. Lanthanum molybdate can act synergistically with phosphates.

\section{Experimental}

Calcium acid phosphate was prepared according to a procedure described elsewhere $[49,50]$. Lanthanum molybdate was prepared by precipitation at pH 5.5 mixing two solutions: $2 \times 10^{-3} \mathrm{M}$ of lanthanum nitrate and $3 \times 10^{-2} \mathrm{M}$ sodium molybdate.

The stoichiometry of the final product was determined by means of current analytical techniques.

The corrosion potential of a SAE 1010 steel electrode was monitored, as a function of time, in the corresponding pigment suspension: $1 \mathrm{~g}$ of the pigment (lanthanum molybdate, calcium acid phosphate or their mixture) was added to $200 \mathrm{~mL}$ of the supporting electrolyte
(0.01 M sodium chloride $\mathrm{NaCl}$ ). A saturated calomel electrode (SCE) was used as reference. After this exposition ( $4 \mathrm{~h}$ ), the morphology of the protective layer formed on the steel panel was observed by scanning electron microscopy (SEM) employing a brand microscope FEI Quanta 200 with tungsten filament. The surface elemental composition of the protective film was obtained with an energy dispersive RX microanalyzer and the EDX detector Apollo 40. Compounds formed on the steel surface were identified by diffuse reflectance infrared Fourier transform spectroscopy analysis (DRIFTS-FTIR).

Corrosion rates were determined by the polarization resistance technique [57-59] employing the Potentiostat-Galvanostat EG \& G PAR Model and a conventional three electrode cell. The working electrode was a SAE 1010 steel rod (area: $0.28 \mathrm{~cm}^{2}$ ), the reference was the SCE and the counterelectrode a Pt mesh. The supporting electrolyte was similar to that employed in corrosion potential measurements but with $0.5 \mathrm{M} \mathrm{NaCl}$. The sweep amplitude was $\pm 20 \mathrm{mV}$ o.c. and the scan rate $0.166 \mathrm{mVs}^{-1}$. All electrochemical measurements were carried out in normally aerated stirred solutions (300 rpm).

Polarization curves, Tafel mode, were done in a similar cell as mentioned above after $2 \mathrm{~h}$ of immersion in $\mathrm{NaCl} 0.5 \mathrm{M}$. In this case, the sweep amplitude was $\pm 250 \mathrm{mV}$ o.c. and the scan rate $1.0 \mathrm{mVs}^{-1}$.

\subsection{Paints composition, preparation and application}

Water-borne paints were formulated containing different amounts of calcium acid phosphate, up to $30 \%$ by volume, with respect to the total pigment content. This value is often recommended for phosphate pigments $[9,10]$. A similar series of paint was formulated by adding $5 \%$ of lanthanum molybdate when the calcium acid phosphate content was diminished below 30\%. Titanium dioxide, barium sulphate, talc and mica were incorporated to complete the pigment formula. Mica was added due to its barrier properties and the ability to reduce "flash rusting" [60-63]. The composition of all the paints could be seen in Table 1 . Paints containing $30 \%$ of calcium acid phosphate and $30 \%$ of lanthanum molybdate, respectively, were used as controls together with a paint without anticorrosion pigments.

The film forming material selected to formulate the water-borne paint was an epoxy resin, based on a mix of bisphenol A and bisphenol F. The curing agent (hardener), which also acts as emulsifier, was a modified polyamidoamine with $50 \%$ of solids. The resin/hardener ratio was $1.0 / 1.2$ by weight. Neutral demineralised water was employed as solvent. PVC was $20 \%$ in order to produce a more impervious coating. Water-borne paint manufacture was carried out employing a high-speed disperser. Preliminary tests showed the advantage of incorporating the pigment into the hardener, instead of mixing it with the resin. Water was added firstly because of the relatively high viscosity of the hardener; then, the pigments were incorporated in accordance with their increasing oil absorption index. Mica was added at the end of the process to avoid the break-up of laminar particles.

SAE 1010 steel panels $(15.0 \times 7.5 \times 0.2 \mathrm{~cm})$ were sandblasted to Sa 2 1/2 (SIS 055900 ), degreased with toluene and then painted by 


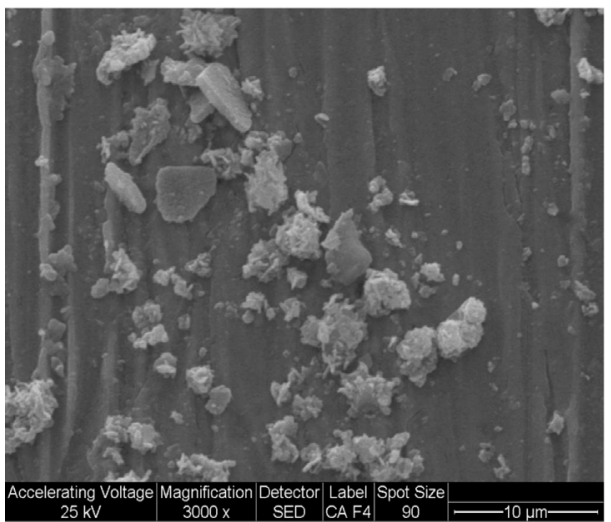

a

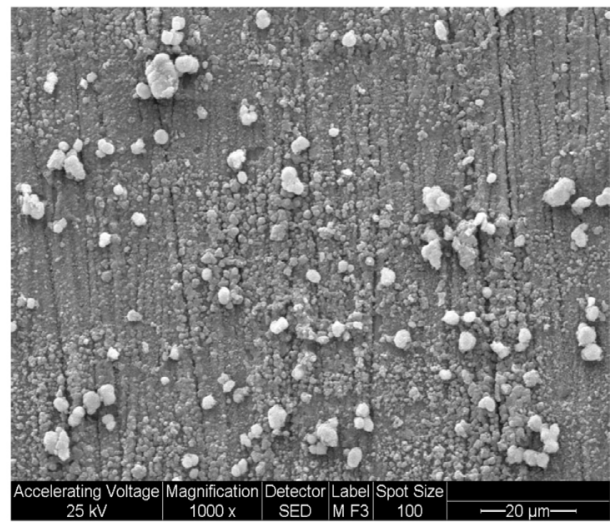

$\mathrm{b}$
Fig. 2. Photographs of steel surface immersed in different pigment suspension. (a) Calcium acid phosphate; (b) Lanthanum molibdate; (c) Calcium acid phosphate + Lanthanum molybdate.

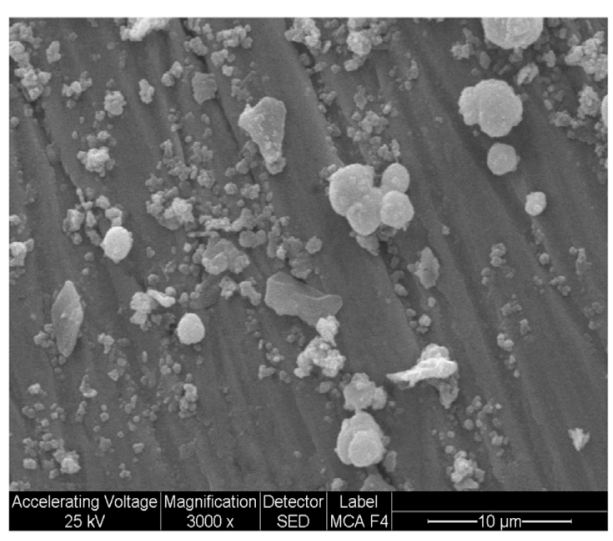

C

brushing. The final film thickness was $75 \pm 5 \mu \mathrm{m}$ and it was accomplished by the application of 3 successive coats. Painted panels were kept indoors for 14 days before being tested.

\subsection{The performance of anticorrosive paints through accelerated tests}

A set of three panels was placed in the salt spray chamber (ASTM B 117) to evaluate the rusting (ASTM D 610) and the blistering (ASTM D 714) degrees. Painted panels were evaluated during $5350 \mathrm{~h}$; the mean value of the obtained results was reported in this paper. A similar set was placed in the humidity chamber (ASTM D 2247); and blistering and rusting degrees were evaluated after 145, 216 and $1180 \mathrm{~h}$.

\subsection{The performance of anticorrosive paints through electrochemical tests}

Ionic resistance: The electrochemical cells employed to measure the resistance between the coated steel substrate and a platinum electrode were constructed by delimiting $3 \mathrm{~cm}^{2}$ circular zones on the painted surface. An acrylic tube $(7.0 \mathrm{~cm}$ high) was placed on the specimen and filled with $0.5 \mathrm{M}$ sodium chloride and measurements were carried out employing an ATI Orion, model 170, conductivity meter, at $1000 \mathrm{~Hz}$. The resistance of the coating was calculated from the conductivity measurements taking into account that the resistance of the solution is neglected.

Electrochemical noise meassurements: The cell for ENM was constituted by two nominally identical electrodes and a reference electrode. A low value resistor $(1.2 \Omega)$ was placed between the two specimens and current noise was measured as the fluctuation in voltage across the resistor, on the grounds that interferences from the electronic circuitry will be diminished [64]. The three electrodes were in the same container which made it easier to controll the effect of temperature fluctuations. The edges of the specimens were blanked off leaving $37 \mathrm{~cm}^{2}$ of the painted panel exposed to a $0.5 \mathrm{M} \mathrm{NaCl}$ solution. The cell was placed in a Faraday's cage to avoid interferences from external sources. Data were acquired with a NICOLET 310 digital oscilloscope and the corresponding software 310RSWFT. Adequate filtering was provided just to eliminate undesirable signals like line signals [65-67]. The sensitivity of the measuring device in the E-scale was $100 \mu \mathrm{V}$ and $50 \mathrm{nA}$ in current measurements. The sampling frequency was $5 \mathrm{~Hz}$, which is commonly used to study corroding systems [65-67] and data were collected during $800 \mathrm{~s}$. Each set of data was controlled to verify they distribute normally $[68,69]$.

\section{Results and discussion}

Steel corrosion potential in the calcium acid phosphate suspension was displaced to negative values due to the formation of a phosphate layer [1]. Lanthanum molybdate displaced steel corrosion potential to more positive values. The corrosion potential of steel in a mixture of both pigments changed to match the corrosion potential of lanthanum molybdate (Fig. 1). So, the incorporation of lanthanum molybdate seemed to be useful in the sense that it could displace Ecorr to more noble values. In the case of the blank, Ecorr diminished continuously up to $-450 \mathrm{mV}$ at the end of the test.

The protective layer formed on steel in contact with the suspension of calcium acid phosphate was rather compact and exhibited corrosion products accumulated, probably, in defective areas (Fig. 2a). The corrosion products consisted in a phosphated oxides as it could be deduced from the presence of the phosphate absorption bands at 1044, 577 and $521 \mathrm{~cm}^{-1}$ in the DRIFTS-FTIR spectra (Fig. 3a) [70]. The band centered at $1044 \mathrm{~cm}^{-1}$ corresponded to the bond stretching in the phosphate ion while the band in the $600-500 \mathrm{~cm}^{-1}$ was assigned to the bending of the phosphate linkage. Water absorption bands could be appreciated in the region between $3550-3200 \mathrm{~cm}^{-1}$ for the antisymmetric and symmetric $\mathrm{O}-\mathrm{H}$ stretchings and at $1630-1600 \mathrm{~cm}^{-1}$ for the $\mathrm{H}-\mathrm{OH}$ bending.

The protective coating generated by lanthanum molybdate was 

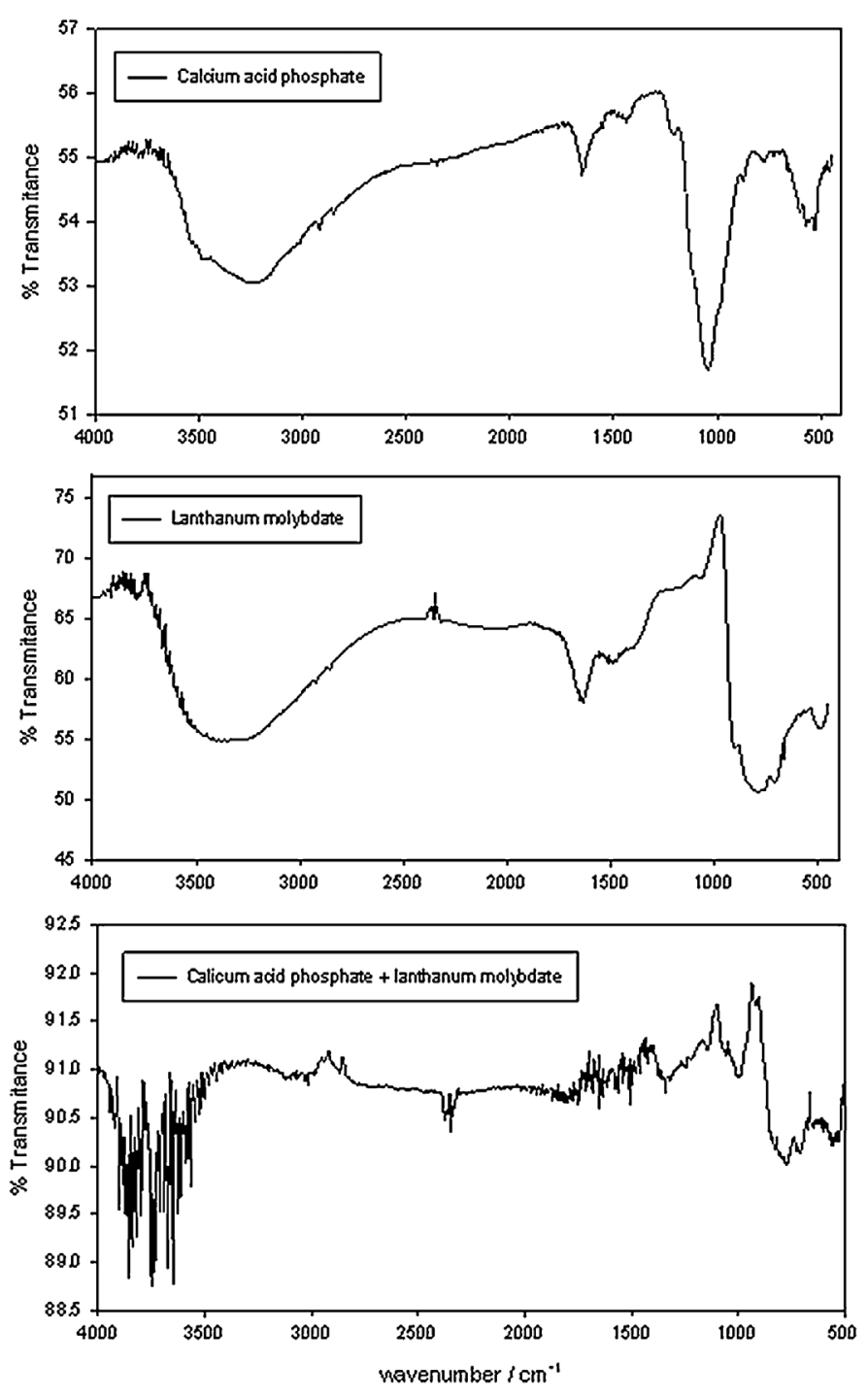

Table 2

SAE 1010 steel corrosion rate (icorr) in pigments suspensions, in $\mathrm{NaCl} 0.5 \mathrm{M}$, as a function of time.

\begin{tabular}{llll}
\hline Pigment & \multicolumn{2}{l}{ icorr $\left(\mu \mathrm{A} \mathrm{cm}^{-2}\right)$} & \\
\cline { 2 - 4 } & $2 \mathrm{~h}$ & $5 \mathrm{~h}$ & $24 \mathrm{~h}$ \\
\hline Calcium acid phosphate & 2.18 & 5.76 & 6.86 \\
Lanthanum molybdate & 32.1 & 24.8 & 24.1 \\
Both pigments & 4.06 & 2.48 & 3.57 \\
Blank (no inhibitor) & 109 & 110 & 131 \\
\hline
\end{tabular}

thick and not as compact as the previous one (Fig. 2b). This may be the reason of the increased corrosion rate. Corrosion products tended to agglomerate on the metal surface and grew following straight lines; some fissures could be appreciated. The composition of the corrosion products was obtained by DRIFTS-FTIR. It consisted of a molybdate layer, probably iron molybdate, according to the broad absorption band centered at $\sim 800 \mathrm{~cm}^{-1}$ (Fig. 3b) [71].

The morphology and composition of the protective layer changed when both inhibitors were employed together (Fig. 2c). The protected layer resulted similar to that of Fig. 2a and the presence of phosphate determined the morphology of the protective layer. The absorption band corresponding to the phosphate detected in the calcium acid phosphate suspension disappeared and a less intense absorption band corresponding to lanthanum
Fig. 3. Diffuse reflectance Infra-red Fourrier transform (DRIFTS-FTIR) spectra of the compounds formed on the steel surface after $4 \mathrm{~h}$ of immersion $\mathrm{NaCl} 0.01 \mathrm{M}$.

phosphate begun to be detected, centered at $1000-1050 \mathrm{~cm}^{-1}$ (Fig. 3c) [70]. The absorption band corresponding to molybdate was still present in the spectrum. It is believed that the formation of a very insoluble layer of lanthanum phosphate restrained the formation of thicker coatings as it occurred in the suspensions of lanthanum molybdate. At the same time, it is thought that this compact layer caused the corrosion rate to be reduced.

Steel corrosion rate was highly reduced by the selected anticorrosive pigments. However, the effect of calcium acid phosphate on corrosion rate was more notorious than that of lanthanum molybdate, particularly during the first hours of testing. However, the mixture of both inhibitors performed a little bit better than each one alone, after $5 \mathrm{~h}$ of exposition. The presence of lanthanum molybdate caused a further reduction in steel corrosion rate with respect to that due to calcium acid phosphate (Table 2).

In Fig. 4 the polarization curves, Tafel mode, of steel immersed for $2 \mathrm{~h}$ in the pigment suspension can be seen. The cathodic current of steel immersed in lanthanum molybdate suspension was similar to the blank (steel immersed in the electrolyte solution), while the anodic current was increased almost 1 order of magnitude. Calcium phosphate and the pigment mixture diminished the anodic and the cathodic currents almost 1 order of magnitude with respect to the blank. However, the cathodic current was higher with both pigments.

Taking into account the electrochemical tests, it is promising to partially replace calcium acid phosphate with lanthanum molybdate in order to diminish phosphate content in the paint. 


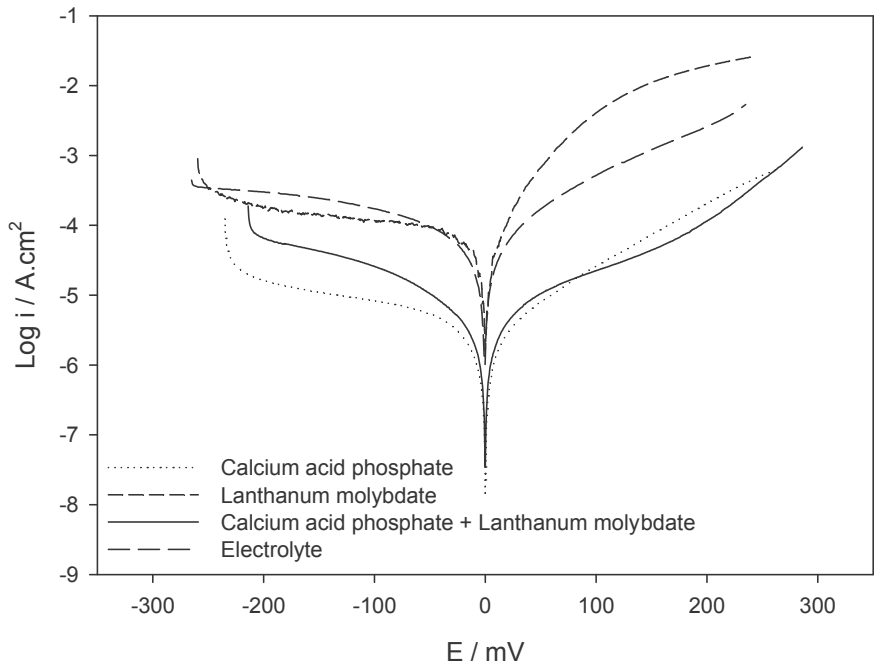

\subsection{The performance of anticorrosive paints through accelerated tests}

Results in the salt spray chamber (Table 3 ) showed that all paints performed satisfactorily after $4300 \mathrm{~h}$ of exposure and outperformed the control paint except paints containing the pigment mixture 3. After $5350 \mathrm{~h}$, paints formulated with mixtures $1,2,5$ and 7 still exhibited a very good anticorrosive behavior. It could be seen that good results could be obtained even with the lowest pigment contents thus revealing the possibility of reducing the anticorrosion pigment loading. Blistering begun after $2570 \mathrm{~h}$ and were smaller than in the case of the blank.

Fig. 5 shows photographs of the panels after removing from the salt spray chamber.

Results in the humidity chamber indicated that blistering begun after $215 \mathrm{~h}$ of exposure and increased as time elapsed (Table 4). In every case the presence of the anticorrosive pigments was beneficial because blisters were of smaller size than in the case of the blank. The surface density of blisters was high, maybe due to the aqueous nature of the binder. Except paint 1, all anticorrosion paints exhibited a good behavior in this chamber, being the rusting degree equal or higher than
Fig. 4. Polarization curves, Tafel mode, of steel immersed in different pigment suspension.

7. In change, corrosion was significant in the control panels (Blank).

\subsection{The performance of anticorrosive paints through electrochemical tests}

The ionic resistance of most paints, at the beginning of the test period, was high and descended drastically before the first fortnight of immersion had elapsed (Fig. 6). After this period the ionic resistance continued decreasing but at a slower rate and its value showed some oscillations due to pore plugging by corrosion products. The exceptions were the paints 5 and 6 which showed the lowest values, but even in these cases, they possessed an acceptable barrier effect [72]. In change, the control paint had poor barrier properties from the beginning of the test but they seemed to increase as time elapsed probably due to the accumulation of corrosion products. After $\sim 30$ days paints 5 and 6 lost most of their barrier effect while the rest of the paints maintained their barrier properties; paints 1-4 beyond 100 days of immersion and paint 7 till $\sim 85$ days of testing. At the end of the test period no barrier effect could be appreciated in any paints.

Fig. 7 shows the noise spectra of the painted panels after 39 days of

Table 3

Assessment of the rusting (R, ASTM D 610) and blistering (B, ASTM D 714) degrees of painted panels in the salt spray test (ASTM B 117).

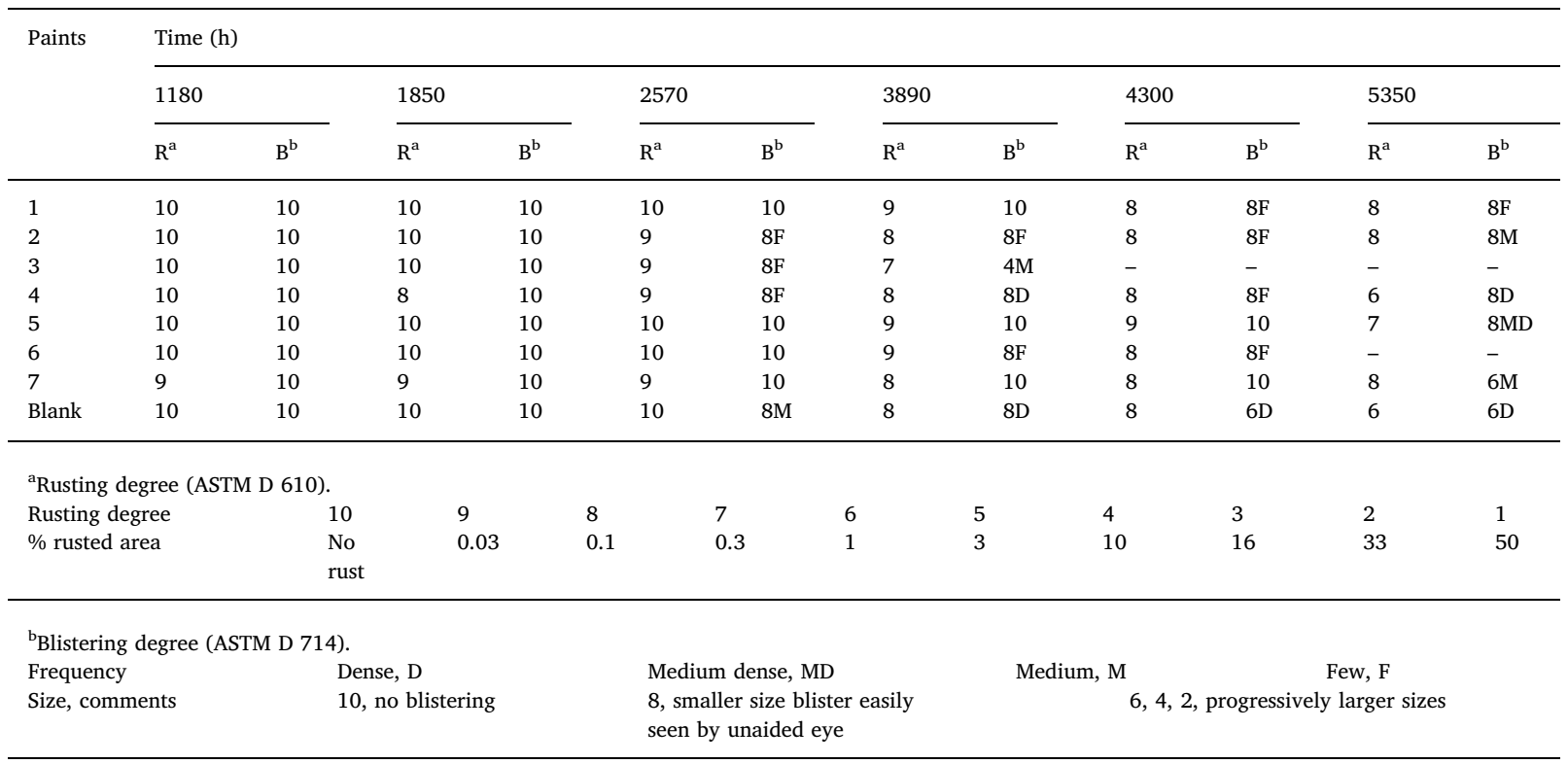



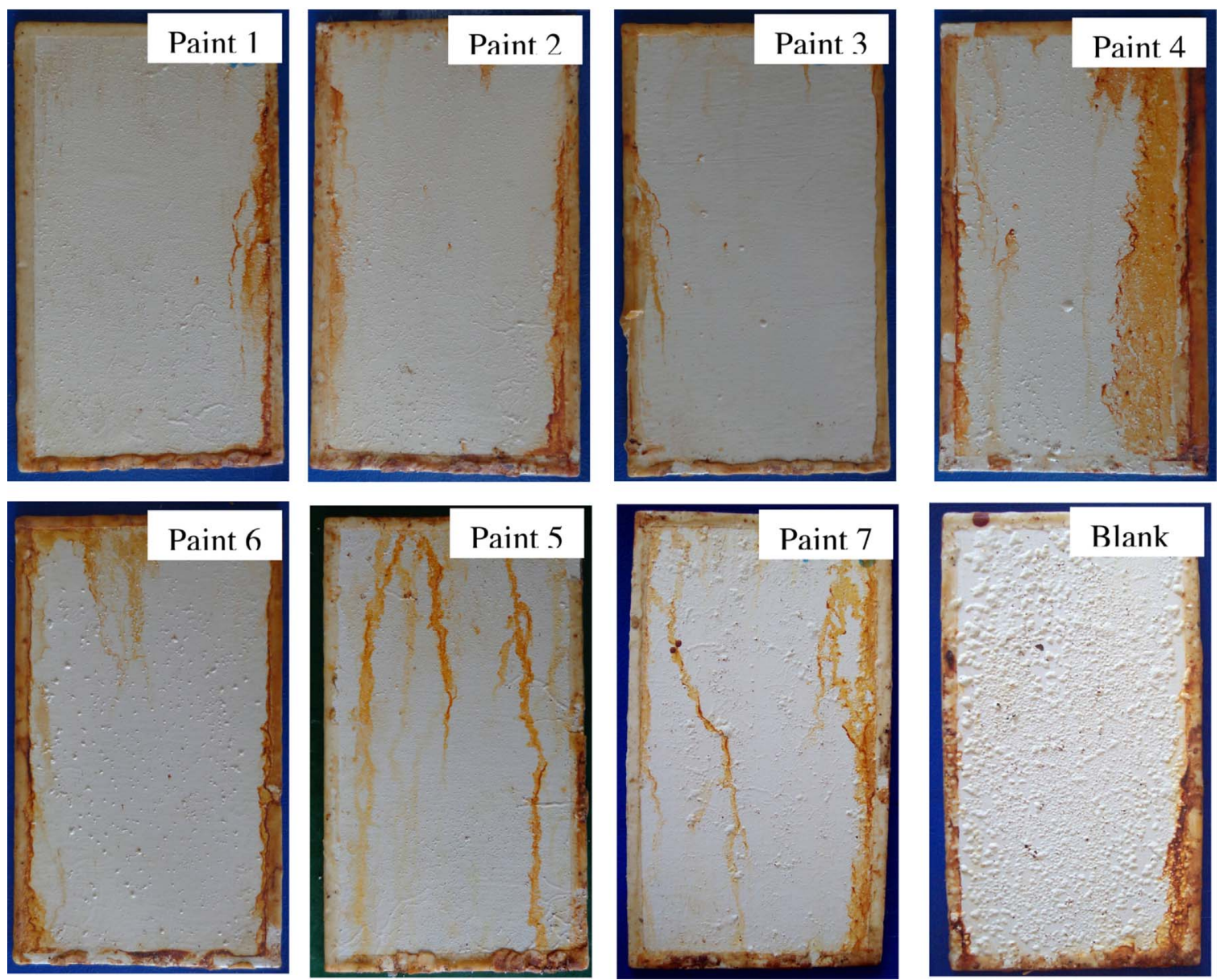

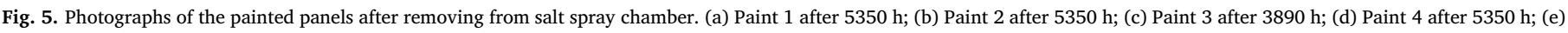
Paint 5 after 5350 h; (f) Paint 6 after 4300 h; (g) Paint 7 after 5350 h; (h) Blank after 5350 h.

assay. It can be seen that the coupling current oscillated $\sim 15 \mu \mathrm{Acm}^{2}$ except in the case of paint 2 . In this case, the corrosion potential was around $-0.015 \mathrm{mV}$ while on the other panels, the potential was more negative, near $-600 \mathrm{mV}$ for paints $1,3,6,7$ and 8 .

According to noise potential measurements, the best anticorrosive behaviour was detected in the case of the paint formulated with $10 \%$ of calcium acid phosphate (paint 4) whose noise potential was maintained displaced to more positive values $(>-0.150 \mathrm{~V})$ during almost 2 months (Fig. 8). A similar behaviour was observed for paint 2 formulated with $15 \%$ of calcium acid phosphate plus $5 \%$ of lanthanum molybdate. The paint containing $30 \%$ of calcium acid phosphate (paint 7) matched, after 1 week of immersion, a potential close to $-0.650 \mathrm{~V}$,

Table 4

Assessment of the rusting (R, ASTM D 610) and blistering (B, ASTM D 744) degrees of painted panels in the humidity chamber (ASTM D 2247).

\begin{tabular}{|c|c|c|c|c|c|c|}
\hline \multirow[t]{3}{*}{ Paints } & \multicolumn{6}{|c|}{ Time (h) } \\
\hline & \multicolumn{2}{|c|}{145} & \multicolumn{2}{|c|}{216} & \multicolumn{2}{|c|}{1180} \\
\hline & $\mathrm{R}$ & B & $\mathrm{R}$ & B & $\mathrm{R}$ & B \\
\hline 1 & 10 & 10 & 10 & $8 \mathrm{D}$ & 6 & $6 \mathrm{D}$ \\
\hline 2 & 10 & 10 & 10 & $8 \mathrm{D}$ & 7 & $6 \mathrm{D}$ \\
\hline 3 & 10 & 10 & 10 & $8 D$ & 9 & $6 \mathrm{D}$ \\
\hline 4 & 10 & 10 & 10 & $8 D$ & 9 & $6 \mathrm{D}$ \\
\hline 5 & 10 & 10 & 10 & $8 \mathrm{D}$ & 10 & $6 \mathrm{D}$ \\
\hline 6 & 10 & 10 & 10 & $8 \mathrm{D}$ & 9 & $6 \mathrm{D}$ \\
\hline 7 & 10 & 10 & 10 & $8 \mathrm{D}$ & 8 & $6 \mathrm{D}$ \\
\hline Blank & 10 & $6 \mathrm{D}$ & 10 & $6 \mathrm{D}$ & 3 & $4 \mathrm{D}$ \\
\hline
\end{tabular}

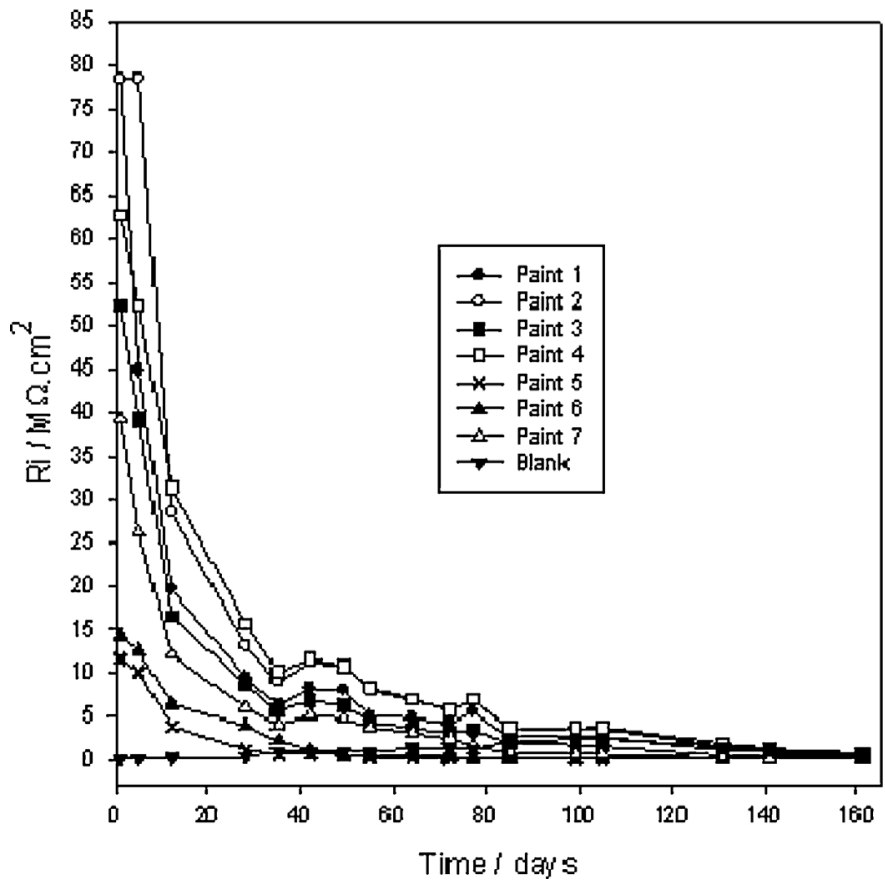

Fig. 6. Ionic resistance of the painted panels. 

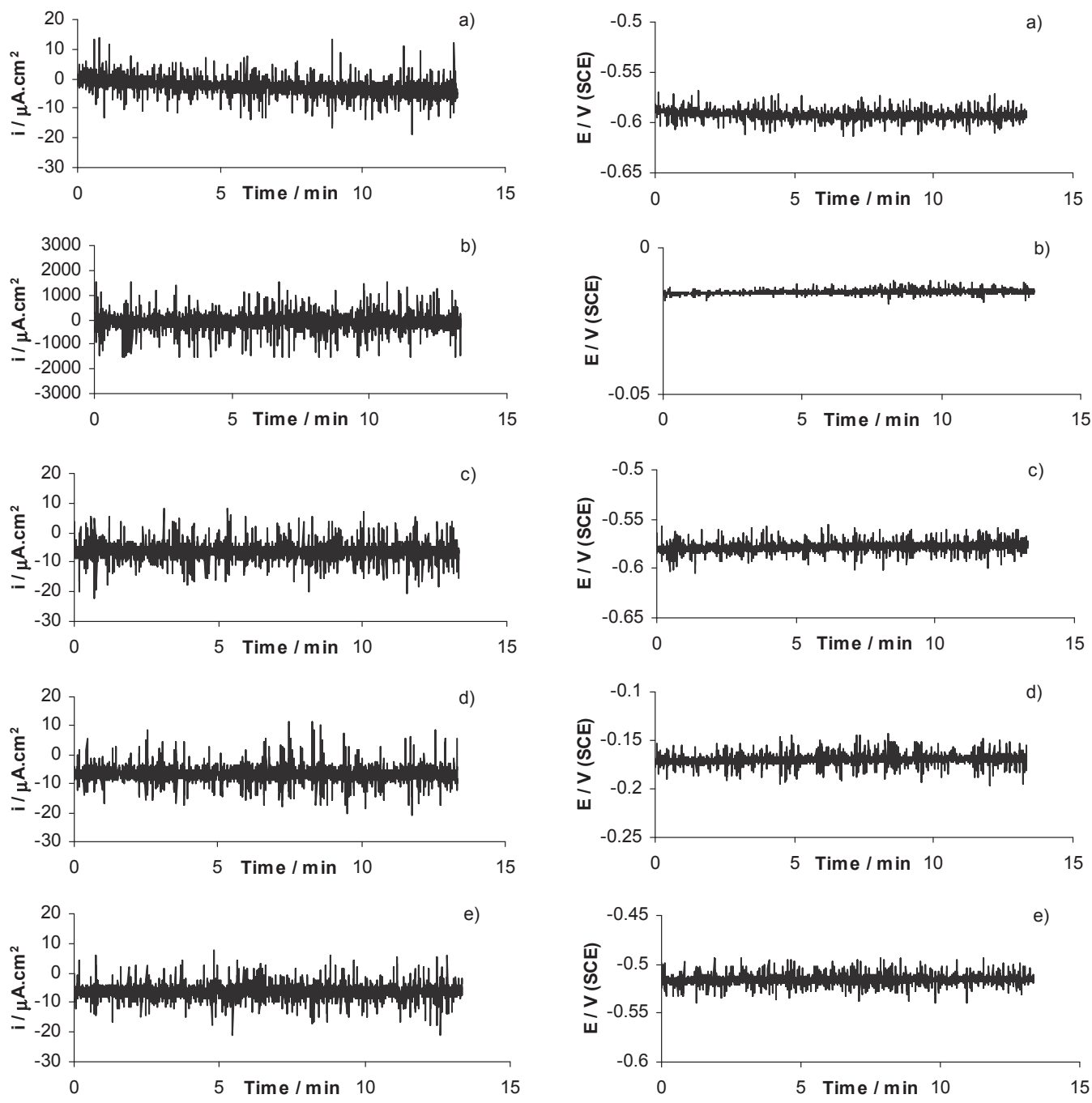

Fig. 7. Typical noise spectra of the painted panels after 39 days of immersion in $\mathrm{NaCl}$ 0.5 M. (a) Paint 1; (b) Paint 2; (c) Paint 3; (d) Paint 4; (e) Paint 5; (f) Paint 6; (g) Paint 7; (h) Blank.

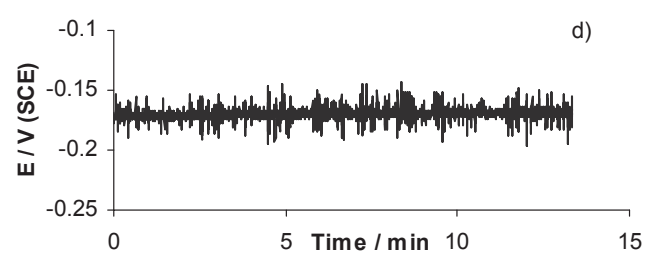

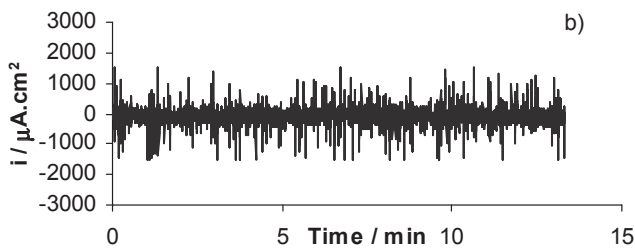
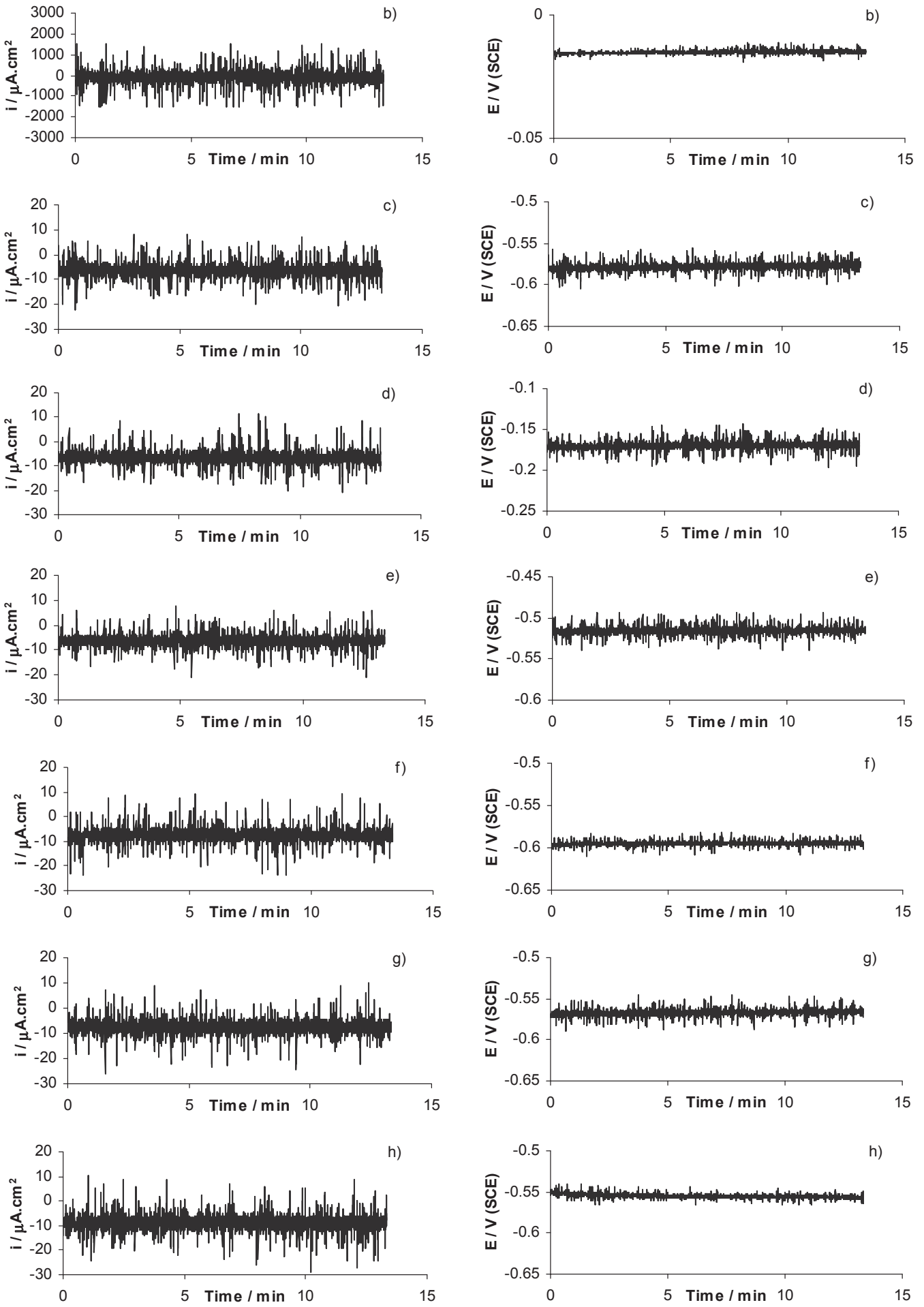

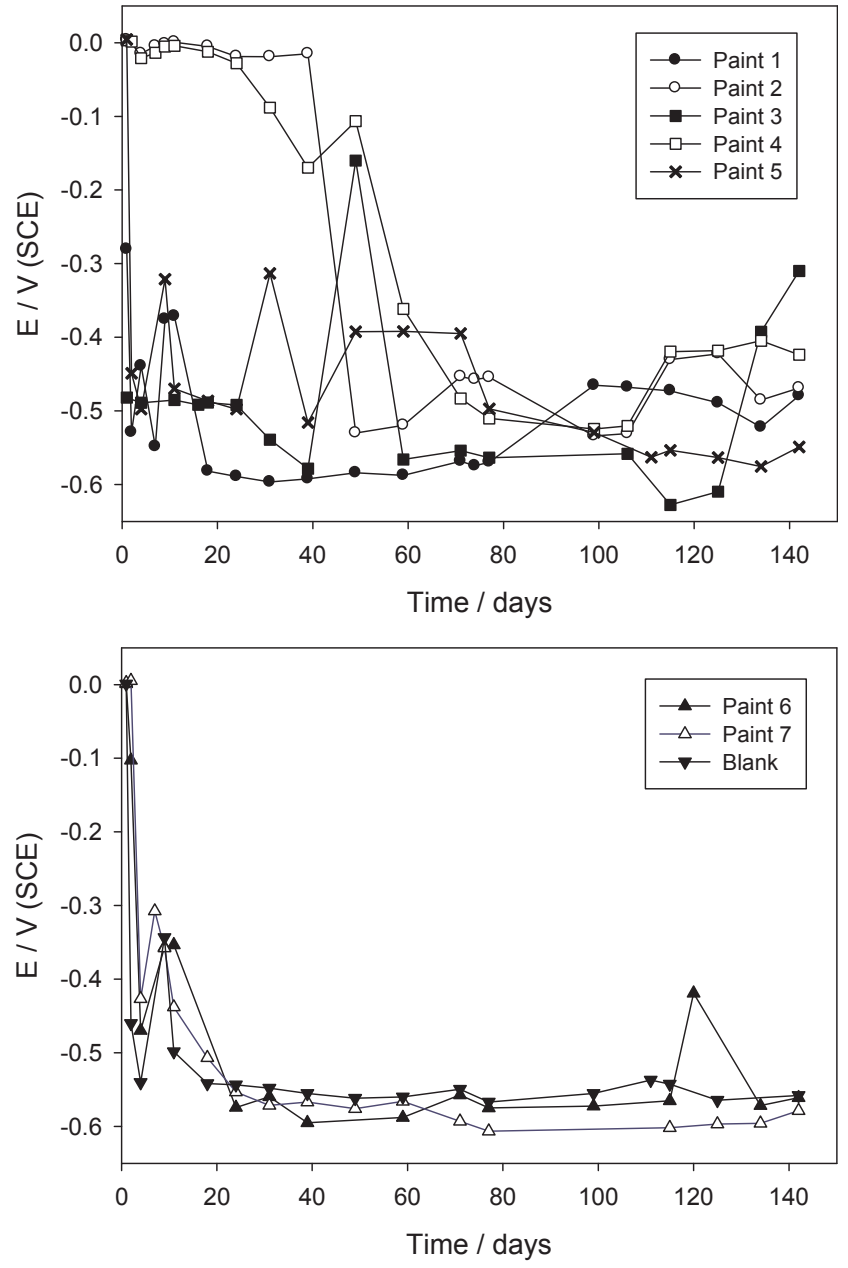

Fig. 8. Corrosion potential of the painted panels.

similar to that of the control. However, the control rusted but the panel with the phosphate paint did not. The paint containing $20 \%$ of this pigment (paint 5) showed an intermediate behaviour; the noise potential oscillated around $-0.400 \mathrm{~V}$ during, approximately, 2 months. The paint with $30 \%$ of lanthanum molybdate (paint 6 ) had a similar behaviour to the paint with the same phosphate content. Noise potential oscillated as time elapsed, thus indicating the existence of active-passive transitions.

As a general rule, the coupling current maintained fluctuating around $7.5 \mu \mathrm{Acm}^{-2}$ during the test period; however, in most cases, it presented strong oscillations either at the beginning or at the end of the test period. Oscillations were attributed to active-passive transitions which take place when pores were plugged with corrosion products (Fig. 9). According to the foregoing discussion, all tested paints had a similar behaviour, except the control coating, whose coupling current begun to increase at the end of the test period.

\section{Final considerations}

As all tested paints presented a certain barrier to ion diffusion, it must be expected that all paints will perform satisfactorily in accelerated tests. This fact was corroborated by results presented in Tables 3 and 4 and Fig. 5. Differences between tested paints, in the salt spray test, could be appreciated at long exposure times; this is from $3890 \mathrm{~h}$ on. However, these differences could be detected earlier during the exposure of painted panels to the humidity chamber. The degradation of the coatings resulted much faster in the humidity chamber than in the salt spray one and the humidity chamber appeared to be
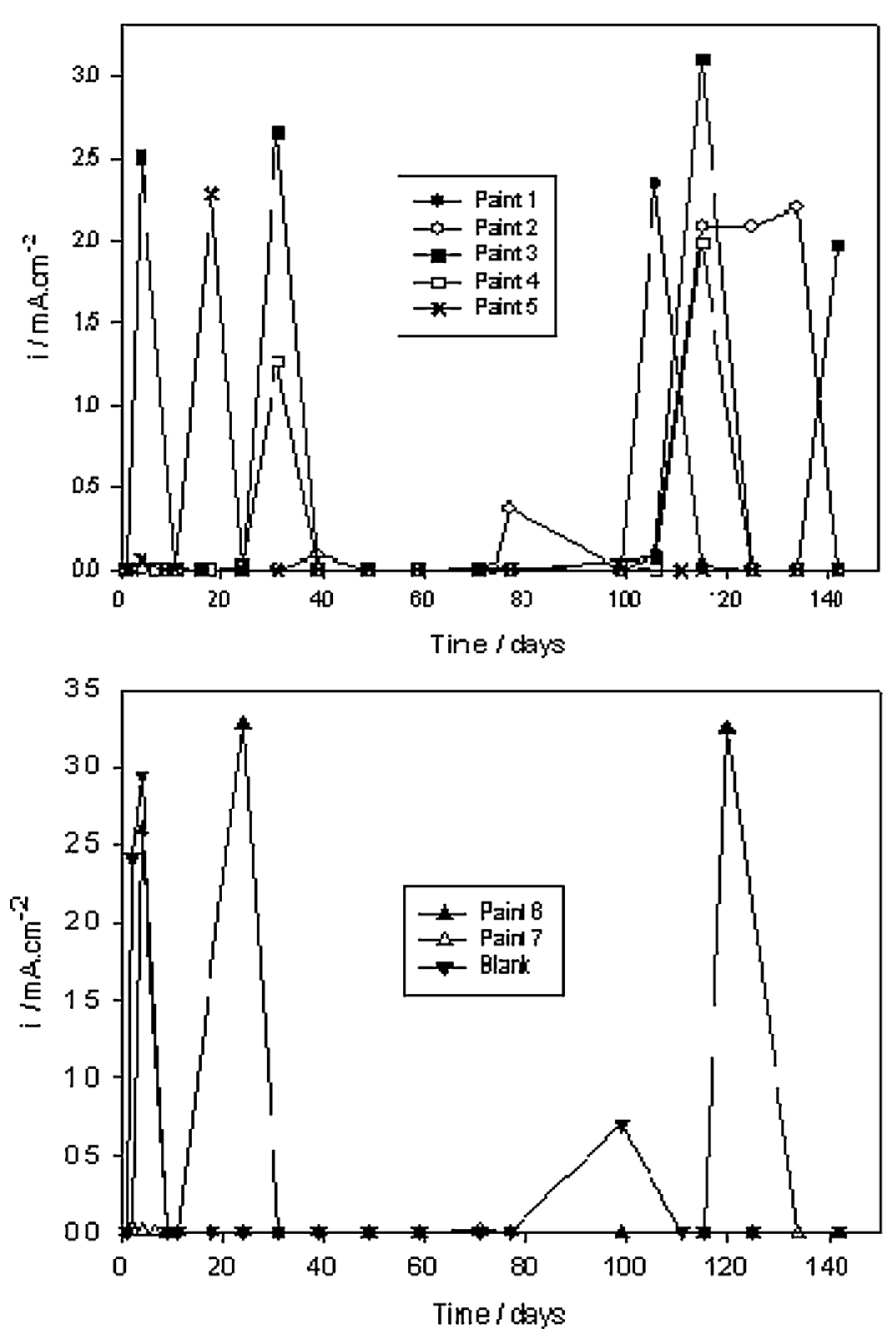

Fig. 9. Current density (i) of the painted panels.

more suitable for the evaluation of this type of coatings. In this sense, Lendvay-Györik et al. [73,74] suggested there are three processes concerning the organic binder, related to the water uptake, which could affect the impedance of the coating. The first process is a fast one and could be attributed to the penetration of the electrolyte solution into the interconnected macropores of the dry films, thus leading to an increased conductivity of the film. A much slower process is the swelling of the polymer accompanied with an increase of the permittivity of the film. Finally, the long-term slow increase of film conductivity may be the result of two processes: the diffusion of the ions from the solution into the bulk of the polymer film and the movement of the charge holding chain ends of the polymer.

The binder is responsible for the barrier properties of the coatings. A proper selection of the binder could result in an improved anticorrosion performance of the coatings. The pigments, as a consequence of their interactions with the binder, may cause the barrier effect to vary as it was observed in the different coatings tested in this research (Fig. 6).

The measurements of paints ionic resistance revealed that the barrier effect was more important than the kinetic inhibition of the corrosion reaction (coupling current, $i \sim 7.5 \mu \mathrm{A} / \mathrm{cm}^{2}$, in every case with some oscillations due to passive-active transitions). The passive-active transitions occurred earlier in the case of paints 3-6 and the blank.

The percentage of anticorrosion pigment played a secondary role and the barrier properties of the coating determined their anticorrosion performance. This was why most pigments mixture seemed to behave satisfactorily in the humidity chamber after $1180 \mathrm{~h}$ of exposition and need a long exposure time to detect some differences in the salt spray 
test. Results suggested that very good results could be obtained with low contents of anticorrosion pigments.

The exposition in the humidity chamber also revealed the importance of employing anticorrosion pigments because the control paint which had an acceptable behavior in the salt spray test failed in the humidity chamber and a clear difference was established between the control and the anticorrosion coatings.

The employment of calcium acid phosphate as anticorrosion pigment appeared to be of crucial importance because it determined the basic characteristics of the protective film, as deduced from SEM observations, and a minimum content of $10 \%$ is recommended for improved anticorrosion performance. Paint 1 , containing $5 \%$ of calcium acid phosphate, showed the poorest anticorrosion behaviour in the humidity chamber. The incorporation of lanthanum molybdate to the pigment formula did not added further advantages in spite of its ability for displacing steel corrosion potential to more positive values.

These conclusions confirmed the results of the electrochemical tests done on pigment suspensions, as the corrosion current was significantly modified by calcium acid phosphate and calcium acid phosphate + lanthanum molybdate but with lanthanum molybdate the results were quite similar to the blank.

\section{Acknowledgements}

This research was carried out in the frame of the scientific co-operation between NKTH (Hungary) and MINCyT (Argentina). The authors wish to thank to: CONICET (Consejo Nacional de Investigaciones Científicas y Técnicas) CICPBA (Comisión de Investigaciones de la Provincia de Buenos Aires) and UNLP (Universidad Nacional de La Plata) for their sponsorship to do this research. Besides, the authors also thank to Christian Byrne for the electrochemical studies.

\section{References}

[1] R. Romagnoli, V.F. Vetere, Heterogeneous reaction between steel and zinc phsophate, Corrosion (NACE) 51 (2) (1995) 116-123.

[2] Z. Szklarska-Smialowska, J. Mankowsky, Cathodic inhibition of the corrosion of mild steel in phosphate, tungstate, arsenate and silicate solutions containing $\mathrm{Ca}^{2}$ ions, British Corr. J. 4 (9) (1996) 271-275.

[3] G. Meyer, Uber Zinkphosphat und Bariumchromat als moderne Korrosionsinhibitoren, Farbe + Lack 69 (7) (1963) 528-532.

[4] J. Barraclough, J.B. Harrison, New leadless anti-corrosive primers, JOCCA 48 (4) (1965) 341-355.

[5] F. de L. Fragata, J.E. Dopico, Anticorrosive behavior of zinc phosphate in alkyd and epoxy binders, JOCCA 74 (3) (1991) 92-97.

[6] R. Romagnoli, V.F. Vetere, Non pollutant corrosion inhibitive pigments: zinc phosphate, a review, Corr. Rev. 3 (81) (1995) 45-64.

[7] M. Svoboda, J. Mleziva, Properties of coatings determined by anticorrosive pigments, Prog. Org. Coat. 12 (1984) 251-297.

[8] L. Chromy, E. Kaminska, Non-toxic anticorrosive pigments, Prog. Org. Coat. 18 (1990) 319-324.

[9] A. Gerhard, A. Bittner, Second generation phosphate anticorrosive pigments. Formulating rules for full replacement of new anticorrosive pigments, J. Coat. Tech. 58 (740) (1986) 59-65.

[10] A. Bittner, Advanced phosphate anticorrosive pigments for compliant primers, J. Coat. Tech. 61 (777) (1989) 111-118.

[11] Y. Hao, F. Liu, E. Han, S. Anjum, G. Xu, The mechanism of inhibition by zinc phosphate in an epoxy coating, Corr. Sci. 69 (2013) 77-86.

[12] S. Yan, W. Heb, C. Sun, X. Zhang, H. Zhao, Z. Li, W. Zhou, X. Tian, X. Sun, X. Han, The biomimetic synthesis of zinc phosphate nanoparticles, Dyes Pig. 80 (2009) 254-258.

[13] R. Romagnoli, B. del Amo, V.F. Vetere, L. Vèleva, High performance anticorrosive epoxy paints pigmented with zinc molybdenum phosphate, Surf. Coat. Int. 83 (1) (2000) 27-32.

[14] B. del Amo, R. Romagnoli, V.F. Vetere, Study of the anticorrosive properties of zinc phosphate and zinc molybdophosphate in alkyd paints, Corr. Rev. 14 (1-2) (1996) $121-133$.

[15] Y. Taketani, H. Kondo, M. Kropman, Propertary aluminum triphosphate pigments for waterborne coatings, PPCJ 183 (4329) (1993) 270-271.

[16] K.G. Jackson, M. Kropman, Novel waterborne high performance steel primer, PPCJ 178 (4129) (1988) 559-561.

[17] M. Takahashi, Characteristics and applications of aluminium triphosphate as special chemical, PPCJ 174 (4133) (1984) 281-284.

[18] K. Kamiya, M. Okuda, M. Okajima, Combination effect of K-White and chromate pigments in coil coatings systems, PPCJ 178 (4228) (1988) 974-978.
[19] J. Nakano, M. Murakami, M. Okuda, Aluminium triphosphate: salt spray studies, PPCJ 177 (4199) (1987) 642-645.

[20] M. Nishihara, G. Nakano, M. Kobayashi, M. Nagita, M. Murakami, Studies on anticorrosive properties of aluminium triphosphate pigments. Corrosion inhibitive properties in alkyd resin coatings system, PPCJ 174 (4125) (1984) 590-597.

[21] T. Noguchi, J. Nahono, M. Kabayashi, M. Nagita, M. Kinugasa, M. Murakami, Studies on anticorrosive properties of aluminium triphosphate pigments. Corrosion inhibitors properties in epoxy resin coatings system, PPCJ 174 (4133) (1984) 888-891.

[22] M. Deyá, V.F. Vetere, R. Romagnoli, B. del Amo, Aluminium tripolyphosphate pigments for anticorrosive paints, Pig. Res. Tech. 30 (1) (2001) 13-24.

[23] V.F. Vetere, M. Deyá, R. Romagnoli, B. del Amo, Calcium tripolyphosphate: an anticorrosive pigment for paints, J. Coat. Tech. 73 (917) (2001) 57-63.

[24] M. Deyá, G. Blustein, R. Romagnoli, B. del Amo, The influence of the anion type on the anticorrosive behaviour of inorganic phosphates, Surf. Coat. Tech. 150 (2002) $133-142$.

[25] M. Deyá, V.F. Vetere, R. Romagnoli, B. del Amo, Zinc tripolyphosphate: an anticorrosive pigment for paints, Surf. Coat. Int. 86 (B1) (2003) 79-85.

[26] R. Naderi, M.M. Attar, Electrochemical study of protective behavior of organic coating pigmented with zinc aluminum polyphosphate as a modified zinc phosphate at different pigment volume concentrations, Prog. Org. Coat. 66 (2009) 314-320.

[27] R. Naderi, M. Mahdavian, A. Darvis, Electrochemical examining behavior of epoxy coating incorporating zinc-free phosphate-based anticorrosion pigment, Prog. Org. Coat. 76 (2013) 302-306.

[28] V. Jaškova, A. Kalendová, Anticorrosive coatings containing modified phosphates, Prog. Org. Coat. 75 (2012) 328-334.

[29] X. Lu, Y. Zuo, X. Zhao, Y. Tang, The influence of aluminum tri-polyphosphate on the protective behavior of Mg-rich epoxy coating on AZ91D magnesium alloy, Electrochim. Acta 93 (2013) 53-64.

[30] A. Kalendová, J. Sňupárek, P. Kalenda, Nontoxic anticorrosion pigments of the spinel type compared with condensed phosphates, Dyes Pig. 30 (2) (1996) 129-140.

[31] E. Alibakhshi, E. Ghasemi, M. Mahdavian, Corrosion inhibition by lithium zinc phosphate pigment, Corr. Sci. 77 (2013) 222-229.

[32] P. Mošner, A. Kalendová, L. Koudelka, Anticorrosion properties of SrO- $\mathrm{ZnO}-\mathrm{B}_{2} \mathrm{O}_{3}$ $\mathrm{P}_{2} \mathrm{O}_{5}$ pigments, Dyes Pig. 45 (2000) 29-34.

[33] A. Kalendová, M. Ulbrich, P. Kalenda, The study of properties of $\mathrm{ZnFe}_{2} \mathrm{O}_{4}$ in organic coatings depending on the structure and morphology of primary particles of $\mathrm{Fe}_{2} \mathrm{O}_{3}$, Transfer inovácií 17 (2010) 68-73.

[34] M. Zubielewicz, W. Gnot, Mechanisms of non-toxic anticorrosive pigments in organic water-borne coatings, Prog. Org. Coat. 49 (2004) 358-371.

[35] N. Granizo, J.M. Vega, D. De La Fuente, J. Simancas, M. Morcillo, Ion-exchange pigments in primer paints for anticorrosive protection of steel in atmospheric service: cation-exchange pigments, Prog. Org. Coat. 75 (3) (2012) 147-161.

[36] N. Granizo, J.M. Vega, D. De La Fuente, B. Chico, M. Morcillo, Ion-exchange pigments in primer paints for anticorrosive protection of steel in atmospheric service: anion-exchange pigments, Prog. Org. Coat. 76 (2-3) (2013) 411-424.

[37] M.L. Petersen, Anti-corrosive Paint Systems Based on Conducting Polymers, Master of Science in Engineering, The Danish Technical University, Denmark, 2006 Master Thesis.

[38] P.P. Deshpande, N.G. Jadhav, V.J. Gelling, D. Sazo, Conducting polymers for corrosion protection: a review, J. Coat. Tech. Res. 11 (4) (2014) 473-494.

[39] J.W. Nicholson, Water-borne coatings: a review of basic principles, JOCCA 70 (1) (1987) 1-4.

[40] P. Swaraj, Water-borne coatings, Surface Coatings. Science and Technology, J. Wiley, Michigan, 1997, pp. 672-713.

[41] M.J. Masciale, Water-bornes and high solids: innovative applications, Eur. Coat. J. 1-2 (1995) 16-27.

[42] C.E.M. van der Kolk, R. Kruijt, E.A. de Rouville, Water-based acrylic dispersion paints for the protection of structural steel; a technology in full development, JOCCA 76 (7) (1993) 280-286.

[43] J.C. Padget, Polymers for water-based coatings - a systematic overview, J. Coat. Tech. 66 (839) (1994) 89-105.

[44] G. Reinhard, Formulation of water-borne dispersions for corrosion-protective primers, Prog. Org. Coat. 18 (1990) 123-245.

[45] E. Spengler, F. de L. Fragata, I.C.P. Margarit, O.R. Mattos, Corrosion protection of low toxicity paints, Prog. Org. Coat. 30 (1997) 51-57.

[46] G. Reinhardt, U. Rammelt, A. Moll, Zur Pigmente von Wasserlacken fur den Korrosionsschutz, Farbe \& Lack 102 (5) (1996) 58-67.

[47] K. Jackson, Recent advances in water-borne protective coatings, Surf. Coat. Int. 82 (1999) 340-343.

[48] K.A. Yasakau, J. Tedim, M.F. Montemor, A.N. Salak, M.L. Zheludkevich, M.G.S. Ferreira, Mechanisms of localized corrosion inhibition of AA2024 by cerium molybdate nanowires, Phys. Chem. C 117 (11) (2013) 5811-5823.

[49] V.F. Vetere, R. Romagnoli, Role of calcium acid phosphate as corrosion inhibitive pigment, British Corr. J. 29 (2) (1994) 115-119.

[50] B. del Amo, R. Romagnoli, V.F. Vetere, Steel corrosion protection by means of alkyd paints pigmented with calcium acid phosphate, Ind. Eng. Chem. Res. 38 (1999) $2310-2314$.

[51] Y.C. Lu, M.B. Ives, The improvement of the localized corrosion resistance of stainless steel by cerium, Corr. Sci. 34 (1993) 1773-1785.

[52] M. Bethencourt, F.J. Botana, J.J. Calvino, M. Marcos, M.A. RodrÍguez-Chacón, Lanthanide compounds as environmentally-friendly corrosion inhibitors of aluminium alloys: a review, Corr. Sci. 40 (1998) 1803-1819.

[53] Y. Zhu, J. Zhuang, Y. Yu, X. Zeng, Research on anti-corrosion property of rare earth inhibitor for X70 steel, J. Rare Earths 31 (2013) 734-740.

[54] Y. Shao, C. Jia, G. Meng, T. Zhang, F. Wang, The role of a zinc phosphate pigment in 
the corrosion of scratched epoxy-coated steel, Corros. Sci. 51 (2009) 371-379.

[55] G.P. Bierwagen, C.S. Jeffcoate, L. Jung Ping, S. Balbyshev, D.E. Tallman, D.J. Mills, The use of electrochemical noise methods (ENM) to study thick, high impedance coatings, Prog. Org. Coat. 29 (1996) 21-29.

[56] F. Mansfeld, H. Xiao, L.T. Han, C.C. Lee, Electrochemical impedance and noise data for polymer coated steel exposed at remote marine test sites, Prog. Org. Coat. 30 (1997) 89-100.

[57] M. Stern, A.L. Geary, Electrochemical polarization: I. A theoretical analysis of the shape of polarization curves, J. Electrochem. Soc. 104 (1) (1957) 56-63.

[58] S. Wolynec, Determinaçao da taxa de corrosão e de outros parâmetros, in: S. Wolynec (Ed.), Técnicas eletroquimicas en corroção, 1st Edition, Editora da Universidade de São Paulo (EdUSP), São Paulo, 2003, pp. 95-114.

[59] F.J. Rodríguez Gómez, Técnicas electroquímicas de corriente directa para la medición de la velocidad de corrosión. Resistencia a la polarización, in: J. Genescá Llongueras (Ed.), Técnicas electroquímicas para el estudio de la corrosión, Laboratorio de corrosión de la Facultad de Química de la UNAM, México, 1989, pp. 1-9.

[60] G. Reinhard, Formulation of water-borne dispersions for corrosion-protective primers, Prog. Org. Coat. 18 (1990) 123-245.

[61] E. Spengler, F. de L. Fragata, I.C.P. Margarit, O.R. Mattos, Corrosion protection of low toxicity paints, Prog. Org. Coat. 30 (1997) 51-57.

[62] G. Reinhardt, U. Rammelt, A. Moll, Zur Pigmente von Wasserlacken fur den Korrosionsschutz, Farbe \& Lack 102 (5) (1996) 58-67.

[63] K. Jackson, Recent advances in water-borne protective coatings, Surf. Coat. Int. 82 (1999) 340-343.

[64] P.R. Roberge, R. Beaudoin, V.S. Sastri, Electrochemical noise measurements for field applications, Corr. Sci. 29 (10) (1989) 1231-1233.
[65] J.R. Kearns, J.R. Scully, P.R. Roberge, D.L. Reichert, J.L. Dawson, Electrochemical Noise Measurements for Corrosion Applications, ASTM, Philadelphia, 1996.

[66] R.A. Cottis, Interpretation of electrochemical noise data, Corrosion 57 (3) (2001) 265-285.

[67] F. Huet, Electrochemical noise technique, in: P. Marcus, F. Mansfeld (Eds.), Analytical Methods in Corrosion Science and Engineering, CRC Taylor \& Francis, USA, 2005, pp. 507-570.

[68] S. Mabbutt, D.J. Mills, C.P. Woodcock, Developments of the electrochemical noise method (ENM) for more practical assessment of anti-corrosion coatings, Prog. Org. Coat. 59 (2007) 192-196.

[69] Y.J. Tan, S. Bailey, B. Kinsella, The monitoring of the formation and destruction of corrosion inhibitor films using electrochemical noise analysis (ENA), Corr. Sci. 38 (1996) 1681-1695.

[70] The Sadtler Standard Spectra, Sadtler Research Laboratories Inc., Inorganic and related compounds, USA, 1976.

[71] F.A. Miller, C.H. Wilkins, Infrared spectra and characteristic frequencies of inorganic ions. Their use in qualitative analysis, Anal. Chem. 24 (8) (1952) 1253-1294.

[72] T. Szauer, Electrical and electrochemical resistances for the evaluation of protective non-metallic coatings, Prog. Org. Coat. 10 (1982) 157-170.

[73] G. Lendvay-Györik, T. Pajkossy, B. Lengyel, Water uptake of water-borne paint resin films as studied by impedance spectroscopy and gravimetry, Prog. Org. Coat. 59 (2007) 95-99.

[74] G. Lendvay-Györik, T. Pajkossy, B. Lengyel, Corrosion-protection properties of water-borne paint coatings as studied impedance spectroscopy and gravimetry, Prog. Org. Coat. 56 (2006) 304-310. 